\title{
ПЕТРОМАГНИТНЫЕ И МИКРОЗОНДОВЫЕ ИССЛЕДОВАНИЯ ПОРОД ПОДВОДНОЙ ВУЛКАНИЧЕСКОЙ ГРУППЫ СОФУ (ИДЗУ-БОНИНСКАЯ ОСТРОВНАЯ ДУГА, ТИХИЙ ОКЕАН)
}

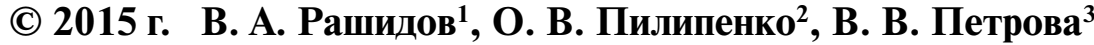 \\ ${ }^{1}$ Институт вулканологии и сейсмологии ДВО РАН \\ 683006 Петропавловск-Камчатский, бульвар Пийпа, 9, \\ e-mail: rashidva@kscnet.ru \\ ${ }^{2}$ Институт физики Земли им. О.Ю. Шмидта РАН \\ 123242 Москва, ул. Б. Грузинская, 10 \\ ${ }^{3}$ Геологический институт РАН \\ 119017 Москва, Пыжевский переулок, 7 \\ Поступила в редакцию 05.10.2014 г.
}

\begin{abstract}
С целью интерпретации результатов исследования аномального магнитного поля дна Тихого океана продолжено комплексное изучение образцов, драгированных в рейсах научно-исследовательского судна “Вулканолог”, и получена информация об их основных ферромагнитных носителях и природе намагниченности. Выполнен анализ естественных магнитных параметров и петромагнитных свойств горных пород, слагающих постройки подводной вулканической группы Софу в Идзу-Бонинской островной дуге. Приводятся результаты термомагнитного, петрологического и микрозондового исследований драгированных образцов. Показано, что основными магнитными минералами-носителями естественной остаточной намагниченности являются неизмененный титаномагнетит и окисленный титаномагнетит. Дифференциация пород по величинам естественной остаточной намагниченности обусловлена различными условиями кристаллизации титаномагнетита, а по магнитной восприимчивости - зависимостью от размера магнитных зерен. Структурные и минералого-петрографические особенности образцов свидетельствуют о том, что они относятся к породам из разных стадий извержений.
\end{abstract}

DOI: $10.7868 / \mathrm{S} 0203030615030049$

\section{ВВЕДЕНИЕ}

Исследование природы аномального магнитного поля подводных вулканов и его связи со строением вулканических построек актуально при изучении Тихоокеанской зоны перехода. Это поле является источником информации не только о строении, но и эволюции подводных вулканов.

Достоверная интерпретация результатов геомагнитных съемок может быть получена при наличии фактических данных о магнитных свойствах пород, слагающих подводные вулканы. Намагниченность, записанная в изверженных породах, ее природа и ферромагнитные зерна-носители могут быть изучены методами магнетизма горных пород.

В настоящее время в рамках комплексного исследования островодужного вулканизма продолжается изучение имеющейся в Институте вулканологи и сейсмологии ДВО РАН коллекции горных пород, драгированных в рейсах научно-исследовательского судна (НИС) “Вулканолог” в период с 1977 по 1991 гг. во время целенаправленного изучения подводных вулканов Тихого океана [Пилипенко, Ра- шидов, 2013; Пилипенко и др., 2012а, 2012б; Рашидов и др., 2014; Rashidov et al., 2012].

С целью интерпретации результатов изучения аномального магнитного поля подводных вулканов Идзу-Бонинской островной дуги проведено комплексное изучение горных пород, слагающих постройки подводной вулканической группы Coфу. На основе термомагнитного, петрографического и электронно-зондового анализов получена информация об основных минералах-носителях намагниченности в образцах и природе их намагниченности.

\section{ПОДВОДНАЯ ВУЛКАНИЧЕСКАЯ ГРУППА СОФУ}

Идзу-Бонинская (Огассавара) островная дуга, известная своей вулканической активностью [Гущенко, 1979; Siebert et al., 2010], состоит из трех вулканических зон: центрального хребта СитоИоджима, четвертичного вулканического фронта и восточного хребта Огасавара.

В 1-ом рейсе НИС “Вулканолог” в 1977 г. в пределах Идзу-Бонинской островной дуги были 
выполнены комплексные геолого-геофизические исследования подводной вулканической группы Софу [Рашидов и др., 1981; Рашидов, Сапожников, 2001], расположенной в южной группе северного звена островной гряды Нампо (рис. 1).

Подводная вулканическая группа Софу представляет собой хребет, протягивающийся в субширотном направлении перпендикулярно простиранию Идзу-Бонинской островной дуги с глубин 2200-2400 м (рис. 2). По контуру подножия хребет имеет длину 50-55 км и ширину 12-25 км [Рашидов, 2010; Рашидов и др., 1981; Рашидов, Сапожников, 2001; Yuasa et al., 1991]. В его привершинной части выделяется цепочка вулканических построек. Восточным окончанием хребта является крупный, размером $17.5 \times 17.5$ км, вулкан Софу. Вершина вулкана в виде скалы (см. рис. 2), которая, по всей видимости, является отпрепарированным некком, поднимается на 100 м выше уровня моря [Yasa et al., 1991]. Скала Софу относится к молодым четвертичным вулканам [Yasa, 1992], а подводная вулканическая группа Софу представляет собой вулканический центр четвертичного возраста. Скала Софу дала название “тектонической линии Софуган”, разделяющая островную дугу Бонин на северную и южную части [Fujiwara et al., 2001; Ueda, 1996; Yuasa, 1985].

В районе скалы Софу к настоящему времени выполнен значительный объем геолого-геофизических исследований [Рашидов, 2010; Рашидов и др., 1981; Рашидов, Сапожников, 2001; Honsa, Таmaki, 1985; Ishihara, 1987; Ishihara, Yamazaki, 1991; Miura et al., 2006; Yamazaki et al., 1991; Yuasa, 1985, 1992; Yuasa, Nochara, 1992; Yuasa et al., 1991].

По данным Аоки (Aoki) и Осака (Ossaka) [Yuasa, Nochara, 1992], скала Софу сложена оливин-клинопироксеновыми базальтами. В 1987 г. японоамериканская экспедиция в рамках программы ALVIN отобрала два образца во время посещения скалы Софу. Образцы представляют собой порфировые андезиты с фенокристаллами плагиоклаза, орто- и клинопироксена и рудных минералов. С южного склона подводного вулкана Софу японскими исследователями в рейсе НИС "Хакури-Мару” были драгированы два образца андезибазальтов [Yuasa, Nochara, 1992].

В 1-ом рейсе НИС “Вулканолог” в пределах вулканической группы Софу было выполнено 16 результативных драгирований [Рашидов, Сапожников, 2001].

В южной части основания вулкана Софу встречены корки лавовых потоков, покрытые железомарганцевым налетом и железомарганцевыми образованиями [Аникеева и др., 2008; Дубинин и др., 2008]. При опробовании основания вулкана Софу подняты андезибазальты.

При драгировании различных участков двухвершинной подводной горы в центральной части вулканической группы были подняты только крупные обломки пемзы со свежим изломом, которые, по-видимому, слагают покров или потоки, экранирующие двухвершинную гору. На юго-западном отроге хребта драгированы базальты, а на куполообразной горке с высотой 300 м в северозападной части района работ - подушечные лавы базальтового состава.

Анализ результатов драгирования позволил предположить, что глубоководная стадия проявления подводной вулканической деятельности группы Софу характеризуется базальтовым вулканизмом, промежуточная - андезибазальтовым, мелководная - эксплозивно-эффузивным дациандезитовым [Рашидов, Сапожников, 2001].

По своим петрохимическим характеристикам опробованный комплекс пород относится к известково-щелочной серии с несколько повышенной глиноземистостью и является весьма характерным для островных дуг Востока Азии [Бевзенко, 1976]. Вместе с тем, подушечные базальты по содержанию $\mathrm{K}_{2} \mathrm{O}$ и другим петрохимическим характеристикам близки к океаническим толеитам.

На гравиметрических картах в редукции свободного воздуха подводной вулканической группе соответствует отчетливая аномалия субширотного простирания с максимумом в 200 мГал над скалой Софу [Honsa, Tamaki, 1985; Ishihara, Yamazaki, 1991]. На картах аномального магнитного поля $\Delta \mathrm{T}_{\mathrm{a}}$ выделяются дипольные изометрические аномалии субширотного простирания, тяготеющие к нормально намагниченным постройкам подводной вулканической группы [Рашидов, 2010; Рашидов и др., 1981; Рашидов, Сапожников, 2001; Yamazaki et al., 1991; Ueda, 2007]. Размах аномалий, приуроченных к постройкам вулканической группы, достигает 950-1050 нТл. [Рашидов, 2010; Рашидов и др., 1981; Рашидов, Сапожников, 2001; Honsa, Tamaki, 1985].

Эффективная намагниченность построек вулканической группы Софу изменяется от 5.06 до 8.8 А/м. Возраст построек не древнее 700 тыс. лет [Рашидов, 2010; Рашидов и др., 1981; Рашидов, Сапожников, 2001; Ueda, 2007].

Несмотря на значительный объем геомагнитных работ, выполненных в пределах подводной вулканической группы Софу, петромагнитные исследования выполнены только для образцов, драгированных в 1-ом рейсе НИС “Вулканолог”. Массовые исследования естественной остаточной намагниченности (NRM) и магнитной восприимчивости $(\mathrm{K})$ показали, что породы резко дифференцированы по своим характеристикам, причем наиболее магнитными являются свежие неизмененные разности [Рашидов и др., 1981; Рашидов, Сапожников, 2001]. Наибольшей NRM обладают подушечные базальты (табл. 1). Далее следуют пористые, среднепорфировые и порфировые андезибазальты. Все перечисленные породы имеют 


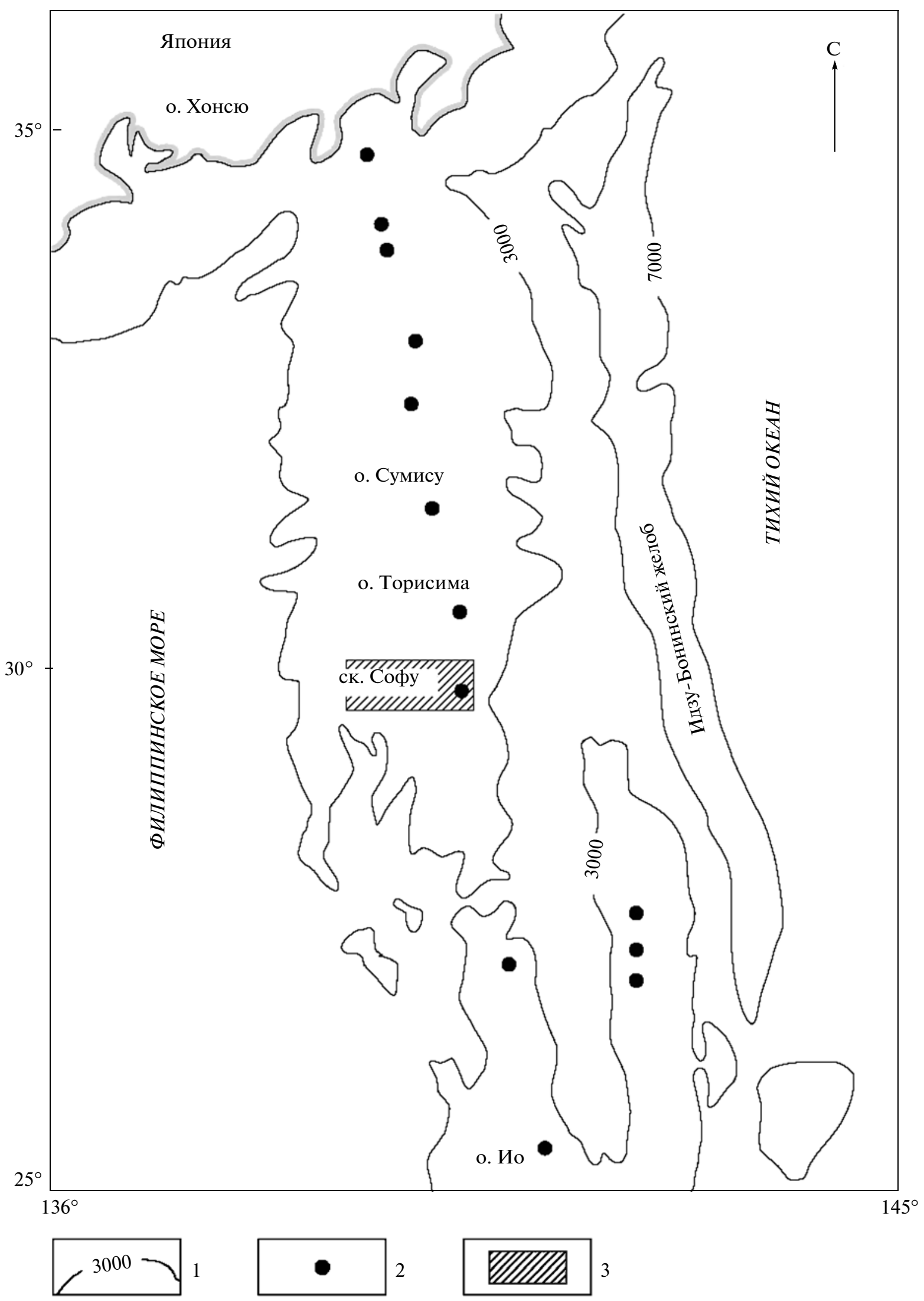

Рис. 1. Местоположение подводной вулканической группы Софу. 1 - изобаты (м); 2 - острова и скалы; 3 - район исследований. 


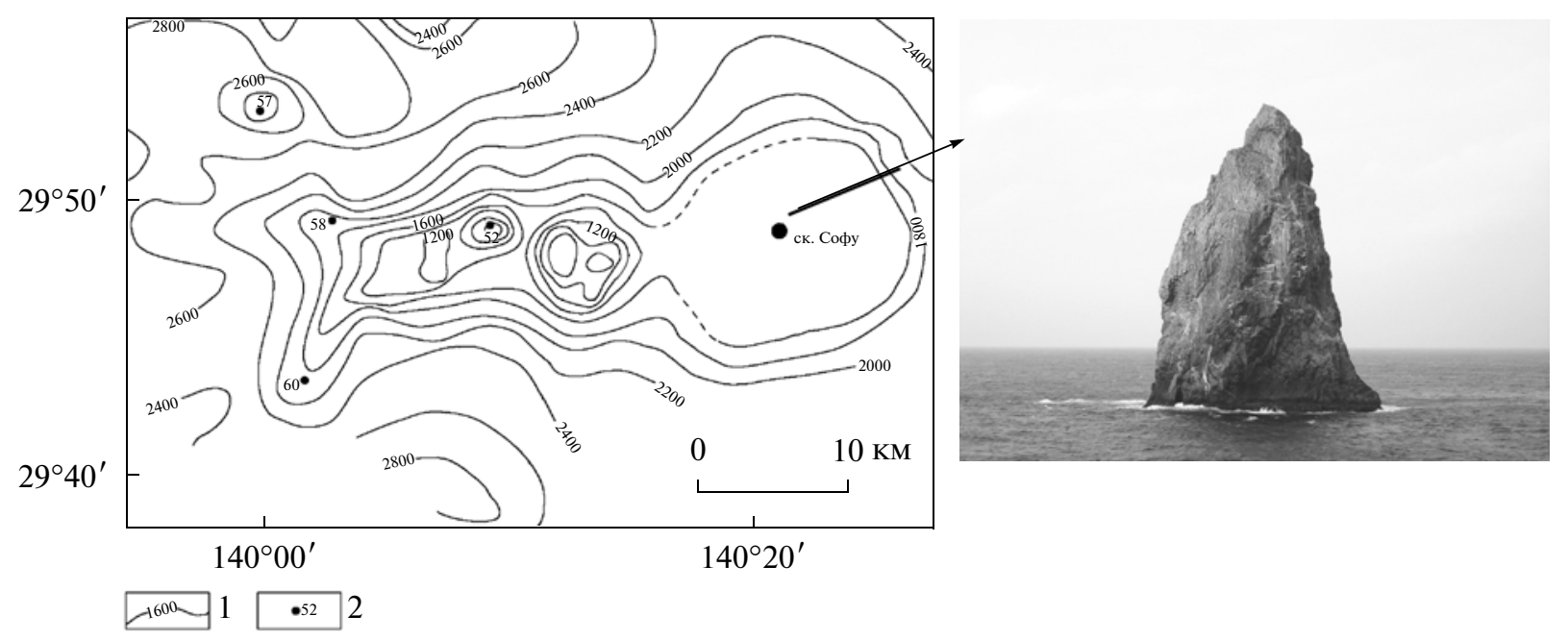

Рис. 2. Батиметрическая карта и места драгирования исследуемых образцов (слева).

1 - изобаты (м); 2 - станции драгирования и их номера. Скала Софу (справа, http://upload.wikimedia.org/wikipedia/commons/3/34/Soufuiwa_07.jpg).

свежий облик без следов вторичных изменений. Остаточная намагниченность остальных пород на порядок ниже. Верхние корки лавовых потоков и пемзы оказались практически немагнитными.

Для выяснения основных носителей естественной остаточной намагниченности в лаборатории "Главного геомагнитного поля и петромагнетизма" Института физики Земли им. О.Ю. Шмидта РАН были выполнены петромагнитные исследования четырех образцов, опробованных в пределах подводной вулканической зоны Софу в драгах В1-52, В1-57, В1-58, В1-60 (см. рис. 2; табл. 2).

\section{МЕТОДИКА ПЕТРОМАГНИТНЫХ ИССЛЕДОВАНИЙ}

Измерения NRM проведены на магнитометре JR-6 (AGICO, Чехия), NRM образцов измерена в трех положениях вращения образца. Магнитная восприимчивость $\mathrm{K}$ и степень анизотропии магнитной восприимчивости $\mathrm{P}^{\prime}$ - на каппаметре Multi-Function Kappabridge (AGICO, Чехия). Чистка переменным магнитным полем на установке переменного поля в трех положениях образца внутри катушки с переменным током, магнитное поле которой может изменяться в преде-

Таблица 1. Магнитные свойства пород, драгированных в пределах подводной вулканической группы Софу

\begin{tabular}{|c|c|c|c|c|}
\hline Порода & $\mid \begin{array}{c}\text { Количество } \\
\text { образцов }\end{array}$ & \begin{tabular}{|c|} 
Средние значения \\
естественной оста- \\
точной намагничен- \\
ности, NRM, A/м
\end{tabular} & $\begin{array}{c}\text { Средние значения } \\
\text { магнитной } \\
\text { восприимчивости, } \\
\mathrm{K} \times 10^{-3} \text {, ед. СИ }\end{array}$ & $\begin{array}{c}\text { Средние } \\
\text { значения фактора } \\
\text { Кенигсбергера, } Q_{n}\end{array}$ \\
\hline Базальты порфировые & 11 & 23.90 & 10.17 & 59 \\
\hline Базальты афировые & 11 & 3.50 & 15.57 & 5.6 \\
\hline Базальты афировые, пористые & 7 & 3.06 & 2.01 & 38.5 \\
\hline Андезибазальты порфировые & 3 & 27.99 & 14.44 & 48.5 \\
\hline Андезибазальты редкопорфировые & 7 & 2.41 & 7.66 & 7.9 \\
\hline $\begin{array}{l}\text { Андезибазальты порфировые, } \\
\text { пористые }\end{array}$ & 11 & 23.31 & 17.58 & 33.2 \\
\hline $\begin{array}{l}\text { Андезибазальты афировые, } \\
\text { пористые }\end{array}$ & 4 & 3.25 & 3.14 & 26 \\
\hline $\begin{array}{l}\text { Андезибазальты афировые, } \\
\text { мелкопористые }\end{array}$ & 2 & 0.85 & 22.48 & 0.9 \\
\hline Вулканическая брекчия & 7 & 0.53 & 5.40 & 2.4 \\
\hline Гравелиты & 3 & 3.83 & 11.55 & 8.3 \\
\hline Пемзы & 43 & 0.01 & 0.89 & 2 \\
\hline
\end{tabular}


Таблица 2. Описание станций драгирования

\begin{tabular}{|c|c|c|c|c|}
\hline \multirow{2}{*}{ № П/П } & \multirow{2}{*}{ № драги } & \multicolumn{2}{|c|}{ Координаты отбора } & \multirow{2}{*}{$\begin{array}{c}\text { Глубинный интервал } \\
\text { отбора, м }\end{array}$} \\
\hline & & широта северная & долгота восточная & \\
\hline 1 & B1-52 & $29^{\circ} 48.9^{\prime}$ & $140^{\circ} 09.1^{\prime}$ & $810-790$ \\
\hline 2 & B1-57 & $29^{\circ} 52.8^{\prime}$ & $139^{\circ} 59.5^{\prime}$ & $2400-2300$ \\
\hline 3 & B1-58 & $29^{\circ} 49.1^{\prime}$ & $140^{\circ} 03.5^{\prime}$ & $2000-1900$ \\
\hline 4 & B1-60 & $29^{\circ} 43.7^{\prime}$ & $140^{\circ} 01.5^{\prime}$ & $2145-2130$ \\
\hline
\end{tabular}

Таблица 3. Петромагнитные характеристики драгированных образцов горных пород

\begin{tabular}{|c|c|c|c|c|c|c|c|c|c|c|c|c|}
\hline $\begin{array}{l}\text { № } \\
\Pi / \Pi\end{array}$ & \begin{tabular}{|c|} 
Номера \\
образцов
\end{tabular} & Описание образцов & $\begin{array}{c}\text { NRM, } \\
\text { A/M }\end{array}$ & $\begin{array}{c}\mathrm{K} \times \\
\times 10^{-3}\end{array}$ & $\mathrm{Q}_{\mathrm{n}}$ & $\mathrm{P}^{\prime}$ & $\begin{array}{l}\mathrm{B}_{\mathrm{cr}} \\
\mathrm{мТл}\end{array}$ & $\begin{array}{l}\mathrm{B}_{0.5}, \\
\text { мТл }\end{array}$ & $\begin{array}{l}\text { Mrs/ } \\
\text { Ms }\end{array}$ & $\mathrm{Bcr} / \mathrm{Bc}$ & $\mathrm{C}, \%$ & $\begin{array}{c}\text { Струк- } \\
\text { тура }\end{array}$ \\
\hline 1 & $\mathrm{~B} 1-52 / 2$ & Андезибазальт афировый & 4.17 & 16.8 & 6.24 & 1.066 & 27 & 70 & 0.101 & & 0.6 & PSD \\
\hline 2 & B1-57/2 & Базальт порфировый & 21.88 & 9.46 & 58.11 & 1.004 & 21 & 40 & 0.256 & & 0.5 & PSD \\
\hline 3 & B1-58/1 & $\begin{array}{l}\text { Андезибазальт } \\
\text { редкопорфировый }\end{array}$ & 4.16 & 17.67 & 5.92 & 1.051 & 27 & 70 & 0.118 & 2.64 & 0.6 & PSD \\
\hline 4 & B1-60/1 & Базальт афировый & 0.39 & 10.71 & 0.92 & 1.039 & 22 & 7 & 0.093 & & 0.4 & PSD \\
\hline
\end{tabular}

Примечание. NRM - естественная остаточная намагниченность; K - магнитная восприимчивость; $\mathrm{Q}_{\mathrm{n}}-$ фактор Кенигсбергера; P' - степень анизотропии магнитной восприимчивости; $\mathrm{B}_{\mathrm{cr}}-$ остаточная коэрцитивная сила; В $0.5-$ медианное поле; Mrs - остаточная намагниченность насыщения; Ms - намагниченность насыщения; С - объемная концентрация ферримагнетика, PSD - псевдодоменные зерна.

лах от 0 до 100 мТл при экранированном внешнем магнитном поле (Applied Physics Systems, USA). Для измерения использовались дубли кубиков с ребром 1 см. На всех образцах была изучена стабильность NRM по отношению к воздействию переменного магнитного поля, т.е. магнитная жесткость медианного магнитного поля. Для этого были сняты кривые размагничивания переменным магнитным полем максимум до величины 100 мТл с шагом 5 мТл.

Проведены исследования состава магнитной фракции путем снятия кривых магнитного гистерезиса, определения значений остаточной коэрцитивной силы Bcr, намагниченности насыщения Ms в поле $\sim 0.8$ Тл на вибромагнитометре (ОРИОН, Россия) и остаточной намагниченности насыщения Mrs на магнитометре JR-6 (AGICO, Чехия). Выполнены три вида термомагнитного анализа (TMA):

1. На вибромагнитометре (ОРИОН, Россия) по намагниченности насыщения Ms в поле $\sim 0.8$ Тл в атмосфере воздуха на образцах объемом $\sim 1 \mathrm{~cm}^{3}$.

2. На каппаметре Multi-Function Kappabridge (AGICO, Чехия) по К(T) на порошкообразных пробах массой $\sim 1$ г.

3. На двухкомпонентном термомагнитометре (ОРИОН, Россия) по зависимости $\mathrm{Mrs}(\mathrm{T})$ на образцах-дублях объемом $\sim 1 \mathrm{~cm}^{3}$ в атмосфере воздуха.

Оценка доменного состояния проведена по величине отношений $\mathrm{Mrs} / \mathrm{Ms}$ и $\mathrm{Bcr} / \mathrm{Bc}$, определен- ным по кривым магнитного гистерезиса [Day et al., 1977].

\section{РЕЗУЛЬТАТЫ ПЕТРОМАГНИТНЫХ ИССЛЕДОВАНИЙ}

Петромагнитные исследования афирового андезибазальта (обр. В1-52/2), редкопорфирового андезибазальта (обр. В1-58/1) и порфирового (обр. В1-57/2) и афирового (обр. В1-60/1) базальтов показали, что образцы имеют относительно высокие значения NRM и К (табл. 3). Степень магнитной анизотропии образцов пород достигала 7\%. Ступенчатое изотермическое намагничивание образцов пород в постоянном магнитном поле характерно для низкокоэрцитивных минералов. Это подтверждают величины остаточной коэрцитивной силы $\mathrm{B}_{\mathrm{cr}}=21-27$ мТл.

TMА по зависимости Mrs (T) на двухкомпонентном термомагнитометре (ОРИОН, Россия) показал, что для образца порфирового базальта B1-57/2 кривая первого нагрева $\operatorname{Mrs}(\mathrm{T})$ имеет точку перегиба в районе $\sim 320^{\circ} \mathrm{C}$ (рис. За). Кривая второго нагрева проходит над ней, необратима и имеет перегиб в районе $\sim 550^{\circ} \mathrm{C}$. Возможно, в этом образце основным носителем намагниченности являлся титаномагнетит $\mathrm{Fe}_{(3-\mathrm{X})} \mathrm{Ti}_{\mathrm{X}} \mathrm{O}_{4}$ с содержанием Ti $(\mathrm{X} \sim 0.35)$, или титаномаггемит. Рост намагниченности после прогрева до $600^{\circ} \mathrm{C}$ и дальнейшего охлаждения связан с протеканием гетерофазного изменения и образованием бедного по содержанию 

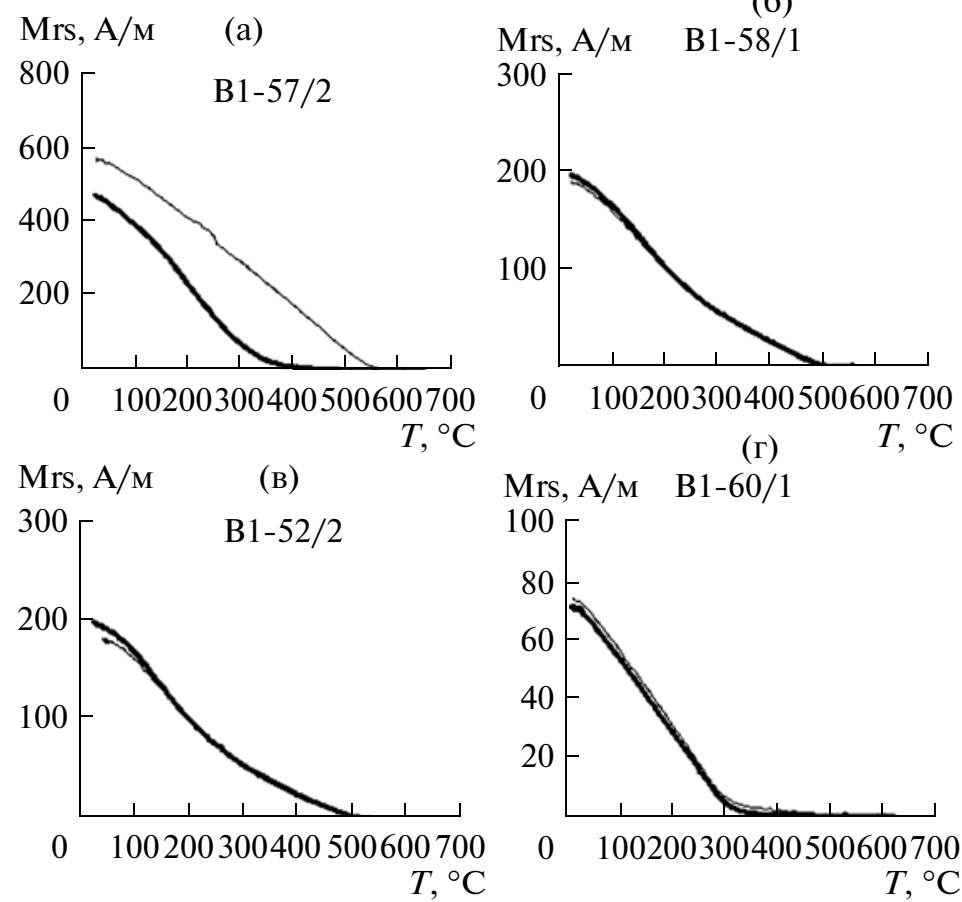

Рис. 3. ТМА по зависимости $\mathrm{Mrs}(\mathrm{T})$ на двухкомпонентном термомагнитометре.

а - образец В1-57/2; б - образец В1-58/1; в - образец В1-52/2; г - образец В1-60/1.

Жирная линия - первый нагрев, тонкая линия - второй нагрев.

Ті титаномагнетита $(\mathrm{X} \sim 0.03)$, близкого по составу к магнетиту, и ильменита [Печерский и др., 1975].

TMA по зависимости $\operatorname{Mrs}(\mathrm{T})$ на образцах редкопорфирового андезибазальта В1-58/1 и афирового андезибазальта В1-52/2 показал, что кривая первого нагрева $\mathrm{Mrs}(\mathrm{T})$ имеет перегиб в районе $\sim 490^{\circ} \mathrm{C}$ (см. рис. 3б, Зв). Кривая второго нагрева обратима, совпадает с кривой первого нагрева (величины Mrs до нагрева и после нагрева практически совпадают), и имеет ту же температуру блокирования. По данным ТМА можно сделать вывод, что в образцах В1-58/1 и В1-52/2 имеют место устойчивые к нагревам зерна титаномагнетита с низким содержанием Тi $(\mathrm{X} \sim 0.11)$, по составу близкие к магнетиту. Возможно, что в этих образцах окисление исходного титаномагнетита уже прошло в естественных условиях [Печерский, Диденко, 1995].

Похожая картина наблюдалась на кривых $\operatorname{Mrs}(\mathrm{T})$ образца афирового базальта B1-60/1. Кривая термомагнитного анализа была обратима, величины Mrs до нагрева и после нагрева практически совпадают, температура блокирования оставалась неизменной (рис. 4г): обе кривые первого и второго нагрева имели перегиб в районе $\mathrm{Tc} \sim 310^{\circ} \mathrm{C}$, что соответствовало содержанию Тi: $\mathrm{X} \sim 0.37$. Не исключено, что окисление первичного титаномагнетита произошло еще в естественных условиях. Этому образцу отвечают относительно низкие значения $\mathrm{NRM}=0.39 \mathrm{~A} / \mathrm{M}$, что, возможно, связано с кристал- лизацией афирового базальта во внутренних частях потоков [Природа..., 1996].

TMA по намагниченности насыщения Ms в поле $\sim 0.8$ Тл в атмосфере воздуха на вибромагнитометре (ОРИОН, Россия) на образце-дубле редкопорфирового андезибазальта В1-58/1 объемом $1 \mathrm{~cm}^{3}$ показал, что в образце присутствуют две ферримагнитные фазы с точками Кюри в районе 290 и $\sim 490^{\circ} \mathrm{C}$ (см. рис. 3). Кривая второго нагрева была обратима и практически повторяла кривую первого нагрева, что подтверждает сделанный вывод о том, что основным носителем намагниченности был устойчивый к нагревам титаномагнетит. Из-за наличия точки Кюри $\sim 290^{\circ} \mathrm{C}$ не исключено присутствие сульфида железа, например, пирротина. Термомагнитный анализ по зависимости магнитной восприимчивости от температуры K(T) в атмосфере воздуха на каппаметре Multi-Function Kappabridge на порошке редкопорфирового андезибазальта В1-58/1 показал, что в образце также присутствуют две ферримагнитные фазы с точками Кюри в районе $\sim 330$ и $\sim 490^{\circ} \mathrm{C}$ (см. рис. 4). Кривая охлаждения имеет единственный перегиб в районе точки Кюри магнетита $\sim 580^{\circ} \mathrm{C}$, не демонстрируя роста магнитной восприимчивости. Точка Кюри в районе $\sim 490^{\circ} \mathrm{C}$ скорее всего отвечает титаномагнетиту $\mathrm{Fe}_{(3-\mathrm{X})} \mathrm{Ti}_{\mathrm{X}} \mathrm{O}_{4}$ с низким содержанием $\mathrm{Ti}$ ( $\mathrm{X} \sim 0.11)$, по составу близкому к магнетиту. Точка Кюри $\sim 330^{\circ} \mathrm{C}$ может соответствовать температуре $\beta$ - превращения пирротина. Характерный горб в 

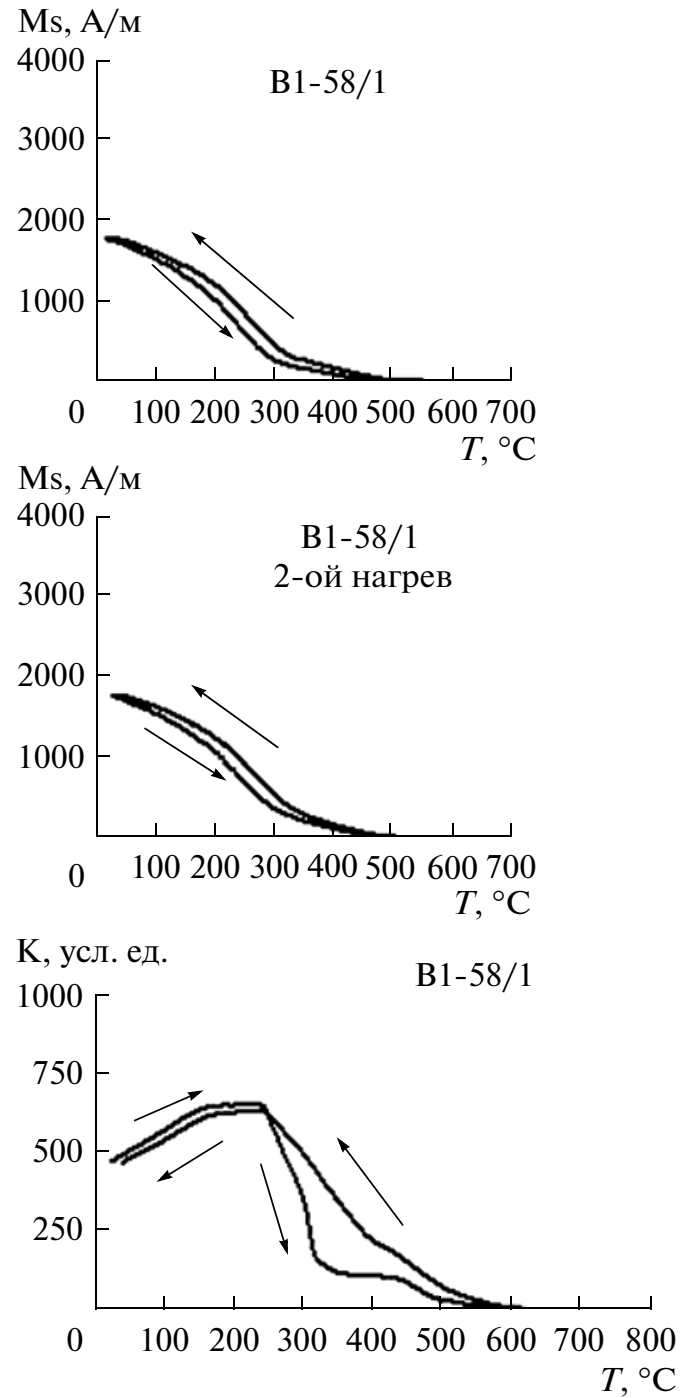

Рис. 4. TMА по зависимостям $\mathrm{Ms}(\mathrm{T})$ на вибромагнитометре и по K(T) на каппаметре Multi-Function Kappabridge для обр. В1-58/1. Стрелками обозначен ход нагрев-остывание.

районе $\sim 240^{\circ} \mathrm{C}$ как на кривой нагрева, так и охлаждения называют $\gamma$ - точкой превращения пирротина $\mathrm{FeS}_{1+\text { x }}$ состава $\mathrm{X}>0.06$ [Нагата, 1965]. Таким образом, основными носителями намагниченности в данном образце являются титаномагнетит и пирротин, которые при нагреве переходят в магнетит.

\section{СТРУКТУРА, МИНЕРАЛЬНЫЙ И ХИМИЧЕСКИЙ СОСТАВЫ ЖЕЛЕЗОСОДЕРЖАЩИХ МИНЕРАЛОВ}

Для подтверждения основных носителей NRM были выполнены микрозондовые определения составов железосодержащих минералов образцов №№ B1-57/2, В1-58/1 и В1-52/2. За неимением добавочного каменного материала образца В1-60/1 порода не анализировалась. Микрозондовый анализ выполнен в Геологическом институте РАН на аналитическом сканирующем электронном микроскопе Cam Scan MV2300. В железосодержащих и ассоциирующих с ними минералах для всех образцов анализировался состав вскрытых при шлифовании центральных зон. В образце В1-58/1 определялся также состав не полированных приповерхностных частей. Так как зондовый анализ не определяет валентность железа при пересчетах средних составов титаномагнетитов на формулу минерала, во всех случаях мы принимали стандартное отношение: две трети трехвалентного железа и одна треть двухвалентного, при пересчете состава хромшпинели, принималось, что это соотношение равно $1: 1$.

Образец В1-57/2 представляет собой базальт, в котором гломеропорфировые вкрапленники оливина (размером до 0.5 мм) погружены в стекловатую основную массу, слабо раскристаллизованную на микролиты пироксена и реже плагиоклаза (рис. 5a).

Встречаются очень редкие вкрапленники титаномагнетита (всего один на площади зоны шлифа $\sim 0.3 \times 0.3 \mathrm{~cm}^{2}$ ) размером 0.05 мм и такие же по размеру редкие вкрапленники пироксена. Из железосодержащих микролитов наиболее распространены мелкие включения хромшпинели в оливине (рис. 6б, точки 32-36; табл. 4). Нужно отметить, что тонкие внешние зоны образца сильно окислены, пористые (см. рис. 5б). Основная стекловатая масса в них раскристаллизована на перистые выделения пироксена и мельчайшие выделения титаномагнетита (см. рис. 5б, точка анализа 47). Внутри поровых пространств присутствуют выделения самородного железа (см. рис. 5б; табл. 5, точка анализа 43).

Титаномагнетит. Три анализа в краевых и центральной частях единого вкрапленника (см. рис. 6а; табл. 4, точки 40-42) показали, что в центральной наиболее чистой части зерна присутствуют только минералообразующие элементы ( Fe, Ti, Al, V, Mg), в краевых зонах к ним добавляются Si и Mn. На снимке отчетливо видно, что вкрапленник окружен плотной коркой нераскристаллизованного стекла, возможно, присутствие последних двух элементов, можно объяснить “захватом” их из этой корки. Однако определить, когда произошел этот захват, при кристаллизации вкрапленника или при его анализе зондом, в настоящее время невозможно. При пересчете на формулу предполагалось, что трех- и четырехвалентные катионы изоморфно замещают трехвалентное железо или титан, а двухвалентные двухвалентное железо. 
Таблица 4. Химический состав железосодержащих минералов (обр. В1-57/2, вес. \%)

\begin{tabular}{|c|c|c|c|c|c|c|c|c|c|}
\hline \multirow{3}{*}{$\begin{array}{c}\text { Минерал } \\
\text { размер } \\
\text { зерна, мкм }\end{array}$} & \multicolumn{5}{|c|}{ Хромшпинель } & \multicolumn{4}{|c|}{ Титаномагнетит } \\
\hline & \multicolumn{6}{|c|}{ микролиты } & \multicolumn{3}{|c|}{ вкрапленник } \\
\hline & $16 \times 18$ & $20 \times 20$ & $20 \times 20$ & $30 \times 30$ & $30 \times 30$ & $10 \times 10$ & \multicolumn{3}{|c|}{$45 \times 55$} \\
\hline точка анализа & 32 & 33 & 34 & 35 & 36 & 47 & 40 & 41 & 42 \\
\hline $\mathrm{MgO}$ & 14.57 & 13.18 & 12.60 & 12.70 & 11.67 & 3.22 & 3.95 & 2.95 & 2.92 \\
\hline $\mathrm{Al}_{2} \mathrm{O}_{3}$ & 33.25 & 25.79 & 22.44 & 22.94 & 22.30 & 4.69 & 4.51 & 3.15 & 4.72 \\
\hline $\mathrm{SiO}_{2}$ & 10.04 & 0.00 & 1.60 & 4.61 & 1.10 & 27.64 & 1.85 & 0.00 & 3.45 \\
\hline $\mathrm{K}_{2} \mathrm{O}$ & 0.00 & 0.00 & 0.00 & 0.00 & 0.00 & 0.62 & 0.00 & 0.00 & 0.00 \\
\hline $\mathrm{CaO}$ & 1.06 & 0.00 & 0.00 & 0.00 & 0.38 & 3.47 & 0.66 & 0.00 & 0.00 \\
\hline $\mathrm{Cr}_{2} \mathrm{O}_{3}$ & 22.53 & 34.38 & 30.47 & 29.29 & 32.91 & 0.00 & 0.00 & 0.00 & 0.00 \\
\hline $\mathrm{TiO}_{2}$ & 0.00 & 0.98 & 0.97 & 0.88 & 0.00 & 9.22 & 9.48 & 10.22 & 10.52 \\
\hline $\mathrm{V}_{2} \mathrm{O}_{5}$ & 0.00 & 0.00 & 0.00 & 0.00 & 0.00 & 0.00 & 1.05 & 1.10 & 1.32 \\
\hline $\mathrm{MnO}$ & 0.00 & 0.00 & 0.00 & 0.00 & 0.00 & 0.00 & 0.00 & 0.00 & 0.71 \\
\hline $\mathrm{FeO}$ & 18.55 & 25.67 & 31.92 & 29.58 & 31.64 & 51.14 & 78.50 & 82.58 & 76.36 \\
\hline Сумма & 100.00 & 100.00 & 100.00 & 100.00 & 100.00 & 100.00 & 100.00 & 100.00 & 100.00 \\
\hline
\end{tabular}

Пересчет анализа в точке № 41 (наиболее чистого зерна титаномагнетита) приводит к следующей формуле титаномагнетита:

$$
\left(\mathrm{Fe}_{0.79}^{+2} \mathrm{Mg}_{0.15}\right)_{0.94}\left(\mathrm{Fe}_{1.56}^{+3} \mathrm{Ti}_{0.26} \mathrm{Al}_{0.13} \mathrm{~V}_{0.02}\right)_{1.97} \mathrm{O}_{4.00} \text {. }
$$

В этой формуле наблюдается небольшой недостаток катионов, как в двухвалентной, так и в трехвалентной позициях. Пересчет среднего (из трех анализов) состава также приводит к несбалансированной формуле:

$$
\left(\mathrm{Fe}^{+2}{ }_{0.76} \mathrm{Mg}_{0.07} \mathrm{Mn}_{0.01} \mathrm{Ca}_{0.01}\right)_{0.85}\left(\mathrm{Fe}^{+3}{ }_{1.50} \mathrm{Ti}_{0.26} \mathrm{Al}_{0.17} \mathrm{Si}_{0.05} \mathrm{~V}_{0.02}\right)_{2.00} \mathrm{O}_{4.00} \text {, }
$$

однако на этот раз только в двухвалентной позиции.

Как видно из расчетной формулы содержание Ті в титаномагнетите $(\mathrm{X} \sim 0.26)$, что с учетом вклада изоморфных примесей соответствовало бы расчетной точке Кюри Тс $\sim 322^{\circ} \mathrm{C}$, хорошо согласующейся с определенной по ТМА $\left(\mathrm{Tc}_{\text {эксп }} \sim 320^{\circ} \mathrm{C}\right)$.

Единственный анализ микролита титаномагнетита из зоны окисления образца (см. рис. 5б, точка 47), показал высокую примесь кремнезема, которая не позволяет пересчитать состав минера- ла на формулу и классифицировать минерал, как чистую разновидность.

В зоне окисления встречено также несколько зерен слабоокисленного самородного железа (см. табл. 5).

Хромшпинель. В образце В1-57/2 большая часть микролитов ассоциирует с вкрапленниками оливина (см. рис. 6б). Состав микролитов приведен в табл. 4. Пересчет среднего (из 5 анализов) состава (из предположения равного количества двух- и трехвалентного железа) приводит к формуле минерала:

$$
\left(\mathrm{Mg}_{0.56} \mathrm{Fe}^{+2}{ }_{0.33} \mathrm{Ca}_{0.01}\right)_{0.90}\left(\mathrm{Al}_{0.87} \mathrm{Cr}_{0.69} \mathrm{Fe}^{+3}{ }_{0.33} \mathrm{Si}_{0.10} \mathrm{Ti}_{0.01}\right)_{2.00} \mathrm{O}_{4.00} \text {. }
$$

В части двухвалентных катионов наблюдается некоторый недостаток, однако очевидно, что $\mathrm{Mg}>$ $>\mathrm{Fe}^{+2}$, a $\mathrm{Al}>\mathrm{Cr}$, что дает основание классифицировать минерал как магнезиальную хромшпинель.

Образец В1-58/1 - пироксен-плагиоклазовый, редкопорфировый андезибазальт с псевдотрахитовой структурой основной массы. В процентном отношении основная масса составляет 75\%, а вкрапленники - 25\%. Во вкрапленниках преоб- ладает плагиоклаз с размером кристаллов, достигающим 1.5 мм. Плагиоклаз образует сростки с моноклинным пироксеном. В небольшом количестве присутствует роговая обманка. Титаномагнетит ( 10\%) представлен отдельными псевдокубическими вкрапленниками размером до $0.4 \times 0.4$ мм или сростками с пироксеном. Особенностью вкрапленников титаномагнетита является тесная связь его поверхности с окружающей стекловатой 

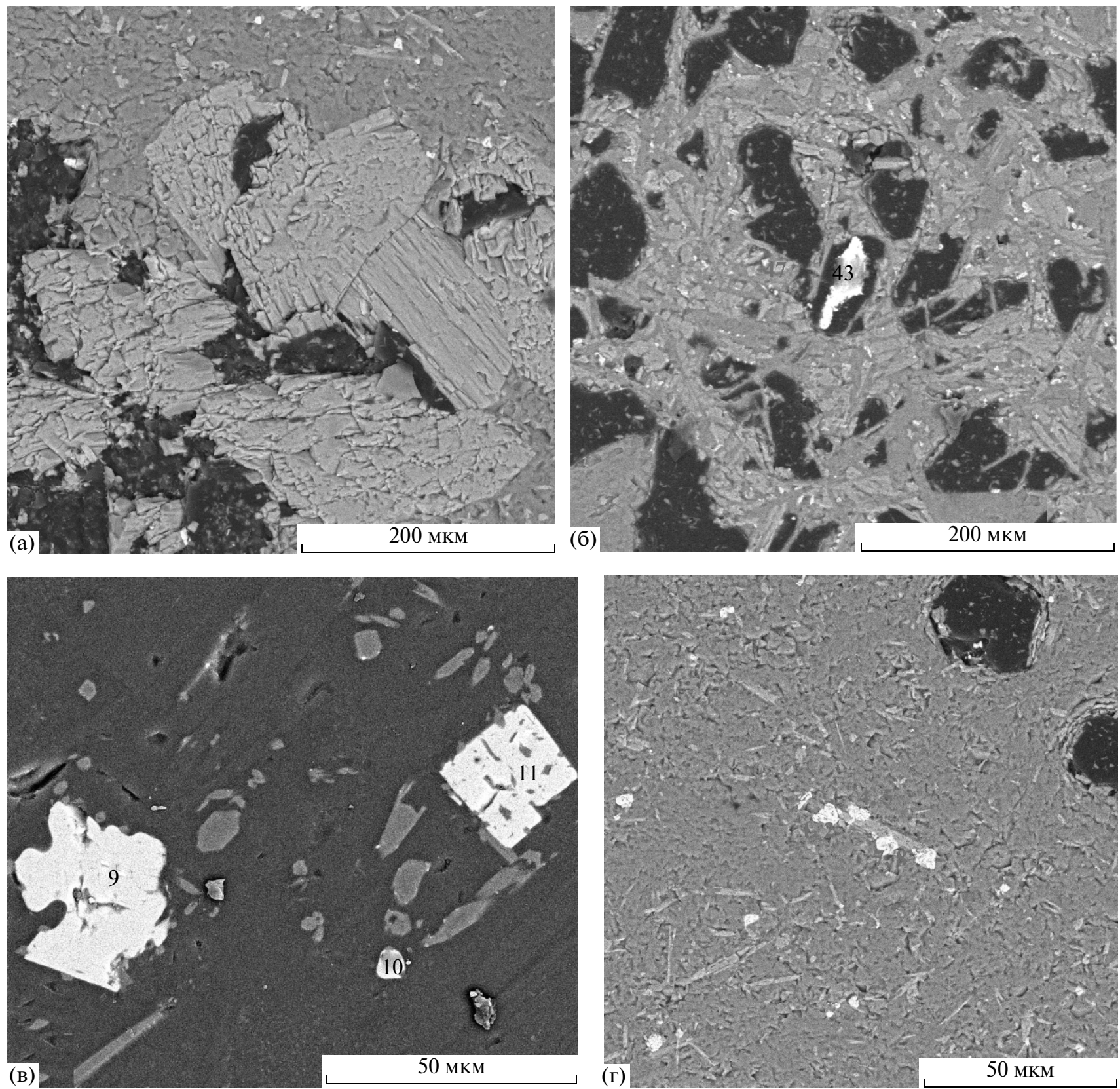

Рис. 5. Облик пород, содержащих вкрапленники и микролиты титаномагнетита.

Образец В1-57/2 (a, б): а - крупный вкрапленник оливина на фоне слабо раскристаллизованной основной массы базальта, где яркие белые точки в оливине и стекловатой основной массы - микролиты хромита, б - закалочная оторочка базальта с перисто-пористой структурой основной массы, раскристаллизованной на пироксен (перистые лейсты) и титаномагнетит (белые точки), где крупное белое зерно в центре газовой пустоты - самородное железо. Образец В1-58/1 (в): участок основной массы породы со слабо выраженной трахитовой структурой, где яркие белые выделения - разноразмерные микролиты титаномагнетита. Роговообманковый андезибазальт В1-52/2 (г): хорошо видны лейсты роговой обманки и микролиты титаномагнетита (белое) на фоне нераскристаллизованного стекла. Арабскими цифрами показаны номера анализов в табл. 4-8.

основной массой. Как видно на рис. 6в тонкая оторочка стекла и стекловатой основной массы (темно-серое) буквально “приклеена" к поверхности титаномагнетита (светлое).

В большей части основной массы около $45 \%$ лейст плагиоклаза, образующих структуру близ- кую к трахитовой. Микролиты титаномагнетита размером 0.02-0.04 мм составляют 15\% основной массы. Остальное - не раскристаллизованное коричневое просвечивающее вулканическое стекло и “зародышевая" тонковолокнистая поздняя роговая обманка. Небольшой участок слабо 
раскристаллизованной основной массы андезибазальта, обогащенный выделениями титаномагнетита, представлен на рис. 6в.

Титаномагнетит. Анализировался состав поверхностных зон отдельных отобранных из тяжелой магнитной фракции зерен разного размера и центральные зоны титаномагнетита в открытых полированных шлифах. Для каждого зерна в разных его местах и зонах делалось несколько анализов, которые показали достаточно однородное распределение Ті и $\mathrm{Fe}$, что позволяет предположить однофазность состава данных зерен.

Следует отметить, что во всех анализах, сделанных с поверхностных зон отобранных образцов, отмечено присутствие кремнезема (от сотых долей до единиц процента). Из семи анализов, сделанных со шлифов (т.е. со срезов по внутренним зонам), только один анализ содержит повышенное количество кремнезема. Это наблюдение, а также наличие стекловатой внешней оторочки, позволили предположить, что кремнезем в анализах захвачен зондом извне и не входит в состав титаномагнетита. Поэтому анализы в таблице 6 приведены в пересчете за вычетом кремнезема (и иногда $\mathrm{CaO}$ и $\mathrm{Na}_{2} \mathrm{O}$ ).

Как видно из таблицы 6, во всех анализируемых кристаллах наблюдается небольшое количество изоморфных примесей $\mathrm{Al}, \mathrm{Mg}$ и $\mathrm{Mn}$, часто присутствует V. Химический состав вкрапленников и микролитов близок, поэтому формула титаномагнетита для образца В1-58/1 рассчитана по среднему составу и она имеет следующий вид:

$\left(\mathrm{Fe}_{0.77}^{+2} \mathrm{Mg}_{0.11} \mathrm{Mn}_{0.02}\right)_{0.90}\left(\mathrm{Fe}_{1.52}^{+3} \mathrm{Ti}_{0.36} \mathrm{Al}_{0.11} \mathrm{~V}_{0.01}\right)_{2.00} \mathrm{O}_{4.00}$,

т.е. отмечается небольшой недостаток в двухвалентной части состава.

Как видно из расчетной формулы, содержание Tі в титаномагнетите $\mathrm{X} \sim 0.36$, что соответствует точке Кюри без учета изоморфных примесей Тс $\sim 310^{\circ} \mathrm{C}$. Данная расчетная температура Кюри даже без учета примесей уже ниже по величине, чем температура, определенная экспериментально различными методами ТМА $\left(\mathrm{Tc}_{\text {эксп }} \sim 490^{\circ} \mathrm{C}\right)$, что говорит о том, что основным носителем NRM являются зерна окисленного титаномагнетита (титаномаггемита) как было предсказано на основе термомагнитного анализа.

Пирротин. Помимо кристаллов титаномагнетита электронно-зондовый анализ также выявил
Таблица 5. Химический состав самородного железа (обр. В1-57/2)

\begin{tabular}{l|r|r|r}
\hline точка анализа & \multicolumn{1}{|c|}{38} & \multicolumn{1}{c}{39} & \multicolumn{1}{c}{43} \\
\hline $\mathrm{O}$ & 3.47 & 2.39 & 0.73 \\
$\mathrm{Si}$ & 4.34 & 3.01 & 2.89 \\
$\mathrm{Mn}$ & 1.00 & 0.62 & 0.75 \\
$\mathrm{Fe}$ & 91.20 & 93.08 & 95.63 \\
$\mathrm{Ni}$ & 0.00 & 0.90 & 0.00 \\
$\mathrm{Cумма}$ & 100.0 & 100.00 & 100.00 \\
\hline
\end{tabular}

присутствие еще одного ферримагнетика, а именно, сульфида железа - пирротина (см. рис. 6г; табл. 7). Поскольку спонтанная намагниченность пирротина почти в 8 раз меньше, чем у титаномагнетита [Паркинсон, 1986], величина остаточной намагниченности главным образом определятся титаномагнетитом, как более сильным ферримагнетиком.

Образец В1-52/2 - Щелочной роговообманковый андезибазальт, афировый, насыщенный газовыми пустотами (см. рис. 5г). На фоне нераскристаллизованного стекла выделяются мелкие (5-10 мкм) слабоориентированные лейсты роговой обманки и точечные микролиты титаномагнетита. Изредка размер роговой обманки достигает 25 мкм или чуть больше. В этом случае она смотрится как микровкрапленник. На рис. бд отчетливы взаимоотношения роговой обманки и титаномагнетита и, несомненно, их образование в одно время. В поле шлифа встречено только одно крупное выделение титаномагнетита. Оно расположено в центральной части газового пространства и представляет собой плотное срастание (друзу) мелких кристаллов (см. рис. 6д).

Титаномагнетит. Проанализирован химический состав 18 отдельных микролитов и одного вкрапленника (в трех местах) (табл. 8). Как видно из таблицы, в микролитах отмечается высокая примесь кремнезема и оксида кальция. По-видимому, захват большей части этих элементов произошло в результате неточности анализа, но исключить нестабильность состава отдельных микролитов также нельзя. Состав вкрапленника более

Рис. 6. Железосодержащие вкрапленники и микролиты.

Образец В1-57/2 (a, б): а - вкрапленник титаномагнетита в основной слабо раскристаллизованной массе породы, б - включения хромшпинели (белое) в оливине. Образец В1-58/1 (в, г): в - крупный вкрапленник титаномагнетита, отобранный из породы, где хорошо видна плотно “припаянная” к зерну титаномагнетита корка стекловатой основной массы, г - ассоциация титаномагнетита (большой серый вкрапленник), пирротина (белые кристаллы) и апатита (темно-серые вростки в титаномагнетите); Образец В1-52/2 (д, е): д - друзовидный вкрапленник титаномагнетита во внутренней части газовой пустоты, е - микролиты титаномагнетита в роговообманковом андезибазальте. Арабскими цифрами показаны номера анализов в табл. 4-8. 

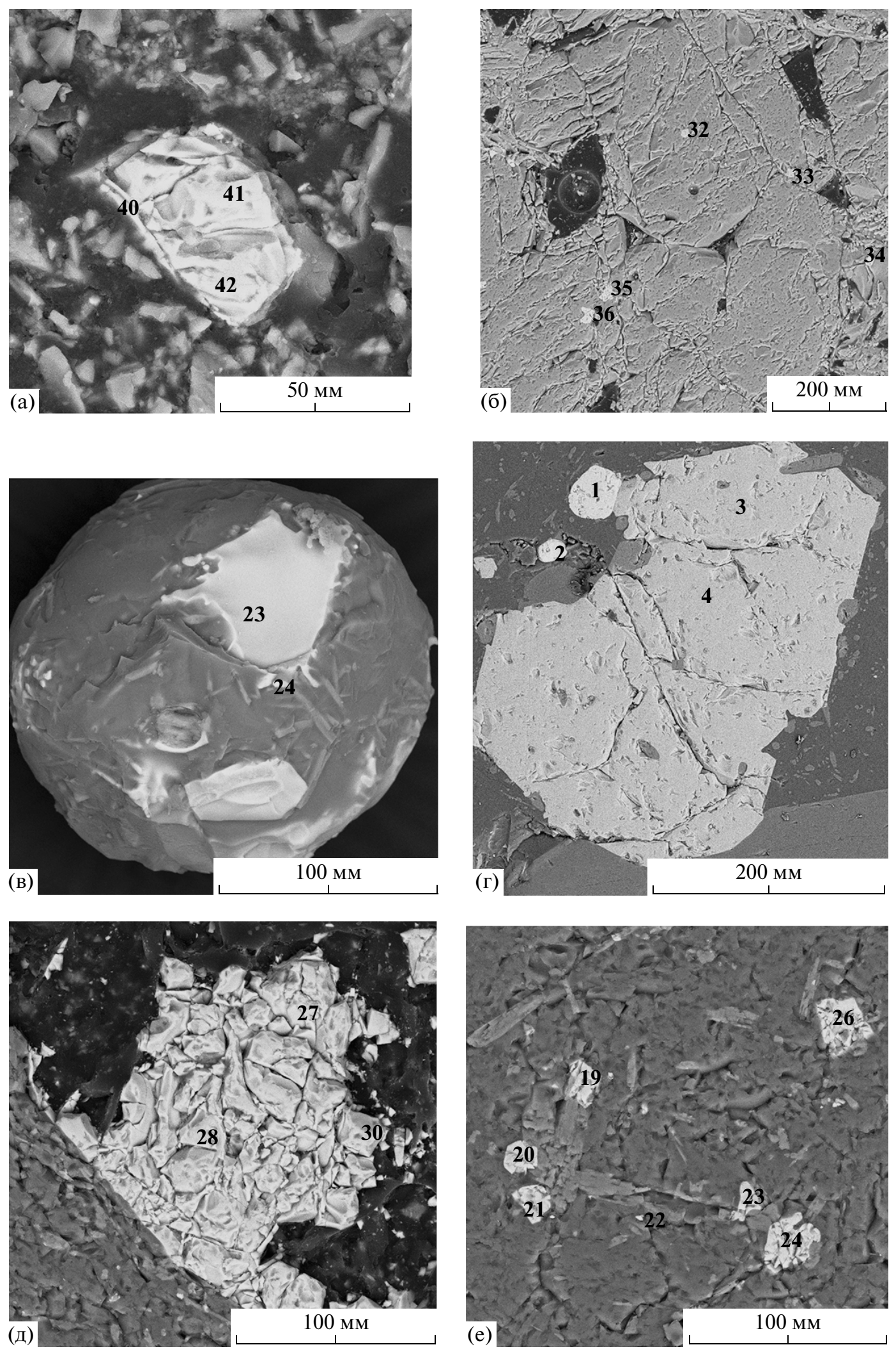
Таблица 6. Химический состав титаномагнетитов обр. В1-58/1

\begin{tabular}{|c|c|c|c|c|c|c|c|c|c|}
\hline \multicolumn{10}{|c|}{ Объемные зерна } \\
\hline размер зерна, мкм & $220 \times 150$ & $150 \times 150$ & $300 \times 300$ & $110 \times 220$ & \multicolumn{2}{|c|}{$200 \times 200$} & $110 \times 200$ & \multicolumn{2}{|c|}{$100 \times 170$} \\
\hline точка анализа & 17 & 18 & 19 & 20 & 23 & 24 & 25 & 26 & 27 \\
\hline $\mathrm{MgO}$ & 2.03 & 4.94 & 2.24 & 1.98 & 2.23 & 1.75 & 0.96 & 1.9 & 2.15 \\
\hline $\mathrm{Al}_{2} \mathrm{O}_{3}$ & 1.8 & 4.48 & 2.1 & 2.2 & 2.44 & 4.8 & 1.81 & 3.19 & 3.31 \\
\hline $\mathrm{TiO}_{2}$ & 13.39 & 13.44 & 13.85 & 13.88 & 16.09 & 14.63 & 13.3 & 12.61 & 13.67 \\
\hline $\mathrm{V}_{2} \mathrm{O}_{5}$ & 0.53 & 0.04 & 0.27 & 0 & 0.49 & 0.17 & 0.64 & 0.57 & 0.06 \\
\hline $\mathrm{MnO}$ & 0.92 & 0.46 & 0.85 & 1.12 & 1.09 & 1.03 & 1.19 & 0.69 & 0.84 \\
\hline $\mathrm{FeO}$ & 81.33 & 76.64 & 80.69 & 80.82 & 77.66 & 77.62 & 82.1 & 81.04 & 79.97 \\
\hline Сумма & 100.00 & 100.00 & 100.00 & 100.00 & 100.00 & 100.00 & 100.00 & 100.00 & 100.00 \\
\hline \multicolumn{8}{|c|}{ Шлифы } & \multirow{4}{*}{\multicolumn{2}{|c|}{$\begin{array}{c}\text { Средний } \\
\text { (из } 16 \text { анализов) } \\
\text { состав титаномаг- } \\
\text { нетита }\end{array}$}} \\
\hline \multirow{2}{*}{ размер зерна, мкм } & \multicolumn{4}{|c|}{ вкрапленники } & \multicolumn{3}{|c|}{ микролиты } & & \\
\hline & \multicolumn{2}{|c|}{$200 \times 400$} & \multicolumn{2}{|c|}{$210 \times 150$} & $25 \times 25$ & $2 \times 2$ & $25 \times 25$ & & \\
\hline точка анализа & 3 & 4 & 6 & 8 & 9 & 10 & 11 & & \\
\hline $\mathrm{MgO}$ & 2.13 & 2.22 & 1.89 & 2.3 & 1.72 & 1.13 & 2.14 & & 11 \\
\hline $\mathrm{Al}_{2} \mathrm{O}_{3}$ & 2.4 & 2.45 & 2.64 & 2.49 & 2.12 & 4.18 & 1.79 & & 76 \\
\hline $\mathrm{TiO}_{2}$ & 13.72 & 13.22 & 13.55 & 14.08 & 16.03 & 11.14 & 15.89 & & 3.9 \\
\hline $\mathrm{V}_{2} \mathrm{O}_{5}$ & 0.66 & 0 & 0 & 0 & 0 & 0 & 0.67 & & 26 \\
\hline $\mathrm{MnO}$ & 0.75 & 0.9 & 0.8 & 0.83 & 1.13 & 0.93 & 1.01 & & 91 \\
\hline $\mathrm{FeO}$ & 80.35 & 81.22 & 81.12 & 80.31 & 78.99 & 82.64 & 78.5 & & 06 \\
\hline Сумма & 100.00 & 100.00 & 100.00 & 100.00 & 100.00 & 100.00 & 100.00 & & .00 \\
\hline
\end{tabular}

постоянен: $\mathrm{CaO}$ - отсутствует, $\mathrm{SiO}_{2}$ - отмечен в малом количестве.

Пересчет среднего состава микролитов приводит к формуле титаномагнетита, в которой отмечается небольшая вакантность трехвалентным катионам и большая по двухвалентным. Пересчет анализа с максимальным количеством железа (точка 24), при сильном недостатке двухвалентных катионов показывает сбалансированность в трехвалентной части:

$$
\left(\mathrm{Fe}_{0.76}^{+2} \mathrm{Mn}_{0.03}\right)_{0.79}\left(\mathrm{Fe}_{1.51}^{+3} \mathrm{Ti}_{0.39} \mathrm{Al}_{0.07} \mathrm{Si}_{0.03}\right)_{2.00} \mathrm{O}_{4.00}-\text { микролит. }
$$

Пересчет состава вкрапленника также дает неудовлетворительный результат:

$$
\left(\mathrm{Fe}_{0.77}^{+2} \mathrm{Mg}_{0.08} \mathrm{Mn}_{0.03}\right)_{0.88}\left(\mathrm{Fe}_{1.52}^{+3} \mathrm{Ti}_{0.34} \mathrm{Al}_{0.09} \mathrm{Si}_{0.01} \mathrm{~V}_{0.01}\right)_{1.96} \mathrm{O}_{4.00} \text { - вкрапленник. }
$$

Таким образом, несомненно, что в щелочном роговообманковом адезибазальте (образец В1-52/2) железосодержащие микролиты и вкрапленники представлены титаномагнетитом, но представляется, что условия его кристаллизации были неравновесными. Свидетельством этого является структура вкрапленника (друзовые сростки мелких кристаллов) и нестабильный химический состав отдельных микролитов.
Расчетные формулы титаномагнетита дают содержание Ti (X 0.34-0.39), что без учета изоморфных примесей соответствует точкам Кюри Тс $\sim 290-315^{\circ} \mathrm{C}$. Данные расчетные точки Кюри даже без учета примесей много ниже, чем температуры, определенные экспериментально ТМА $\left(\mathrm{Tc}_{\text {эксп }} \sim 490^{\circ} \mathrm{C}\right)$, что говорит о низкотемпературном окислении, и что основным носителем NRM являются зерна окисленного титаномагнетита (титаномаггемита). 
Таблица 7. Химический состав пирротина, вес. \%

\begin{tabular}{l|c|c|c}
\hline $\begin{array}{c}\text { Точка } \\
\text { анализа }\end{array}$ & 1 & 2 & 7 \\
\hline $\mathrm{S}$ & 38.04 & 38.80 & 38.64 \\
$\mathrm{Fe}$ & 61.01 & 61.20 & 60.63 \\
$\mathrm{Cu}$ & 0.95 & 0.00 & 0.73 \\
$\mathrm{Cумма}$ & 100.00 & 100.00 & 100.00 \\
Формула & $\mathrm{Fe}_{1.09} \mathrm{Cu}_{0.01} \mathrm{~S}_{1.00}$ & $\mathrm{Fe}_{1.09} \mathrm{~S}_{1.02}$ & $\mathrm{Fe}_{1.08} \mathrm{Cu}_{0.01} \mathrm{~S}_{1.01}$ \\
\hline
\end{tabular}

\section{ОБСУЖДЕНИЕ ПОЛУЧЕННЫХ РЕЗУЛЬТАТОВ}

Проведенные петромагнитные и микрозондовые исследования образцов показали, что основными носителями намагниченности изученных пород подводной группы Софу являются зерна неизмененного и окисленного титаномагнетита, объемная концентрация ферримагнетика в породе C 0.5-0.6\% (см. табл. 3). При расчетах объемной концентрации использовалась экспериментально полученная по кривым магнитного гистерезиса намагниченность насыщения образцов и намагниченность насыщения титаномагнетита, определенная по атомной доли титана [Butler, 1998]. Не выявлено различий доменной структуры для афировых и порфировых разностей - все зерна имеют псевдооднодоменную структуру. Величины NRM изменяются от $\sim 0.39$ до $\sim 21.88$ А/м (см. табл. 3). Величина намагниченности обусловлена тем, на каком магнитном минерале и в каких природных условиях она была создана.

Наиболее основной породой является базальт образца В1-57/2, в которой крупные хорошо образованные, почти идиоморфные вкрапленники оливина погружены в слабо раскристаллизован- ную основную массу. Оливин ассоциирует с хромшпинелью, мелкие кристаллы которой захвачены оливином при его росте и, соответственно, образовались чуть раньше последнего. Наряду с вкрапленниками оливина очень редко в породе присутствуют меньшие по размеру вкрапленники моноклинного пироксена и титаномагнетита.

Условия образования ассоциации оливинхромшпинель хорошо изучены [Бенедюк, 2013; Дир и др., 1965]. Согласно литературным данным, оливин может находиться в равновесии с расплавом в интервале температур 1890-1290 С. При этом, чем выше железистость минерала (как в нашем случае), тем выше температура его кристаллизации. Диапазон температур кристаллизации хромшпинели, включенной в оливин - 1280$1310^{\circ} \mathrm{C}$, а клинопироксена $-1230-1250^{\circ} \mathrm{C}$. Таким образом, можно оценить температуру образования вкрапленников в образце В1-57/2 интервалом $1250-1300^{\circ} \mathrm{C}$, что сопоставимо с температурой глубинной очаговой зоны. Этот вывод подтверждается еще и тем, что Al-хромшпинели (как в нашем случае) формируются в условиях повышенного давления [Бенедюк, 2013], что может свидетельствовать о глубинной, возможно, докамерной кристаллизации вкрапленников хромшпинели и оливина.

Быстрый подъем и излияние лавы фиксируется в слабой раскристаллизации основной массы породы и в образовании корки закалки с перистой структурой основной массы. Только в этой части породы встречаются микролиты титаномагнетита и выделения свободного железа.

Ферримагнитные зерна (вкрапленники) порфирового базальта образца В1-57/2, были закупорены во внутренних частях породы и не подверглись агрессивному воздействию окружающей среды, поэтому они представлены титаномагнетитом с температурой Кюри $320^{\circ} \mathrm{C}$. Эти зерна несут на по-

Таблица 8. Химический состав титаномагнетита образца В1-52/2

\begin{tabular}{|c|c|c|c|c|c|c|c|c|c|c|c|c|c|c|c|c|c|c|c|c|c|}
\hline \multirow{2}{*}{$\begin{array}{c}\text { Точка } \\
\text { ана- } \\
\text { лиза }\end{array}$} & \multicolumn{18}{|c|}{ Микролиты } & \multicolumn{3}{|c|}{ Вкрапленник } \\
\hline & 1 & 2 & 4 & 5 & 7 & 8 & 10 & 11 & 12 & 13 & 17 & 18 & 19 & 20 & 21 & 23 & 24 & 26 & 27 & 28 & 30 \\
\hline $\mathrm{gaO}$ & 1.80 & 2.08 & 3.76 & 4.34 & 2.81 & 2.80 & 1.81 & 1.92 & 0.00 & 0.00 & 1.08 & 1.27 & 1.83 & 1.96 & 0.00 & 0.00 & 0.00 & 0.00 & 1.29 & 2.52 & 0.65 \\
\hline $\mathrm{Al}_{2} \mathrm{O}_{3}$ & 3.79 & 8.57 & 3.25 & 3.43 & 1.82 & 4.1 & 3.57 & 2.15 & 4.73 & 3.74 & 3.39 & 3.31 & 2.93 & 2.88 & 1.87 & 2.35 & 1.64 & 2.09 & 2.24 & 1.64 & 2.7 \\
\hline $\mathrm{SiO}_{2}$ & 0.00 & 11.55 & 3.48 & 10.42 & 1.36 & 7.15 & 7.25 & 2.95 & 25.23 & 15.81 & 8.77 & 15.28 & 4.13 & 12.38 & 1.78 & 1.37 & 1.13 & 2.31 & 0.17 & 0.00 & 0.54 \\
\hline $\mathrm{CaO}$ & 0.92 & 0.72 & 0.85 & 2.14 & 1.56 & 0.56 & 0.55 & 0.00 & 1.01 & 0.92 & 1.29 & 1.22 & 0.54 & 2.37 & 1.24 & 1.29 & 0.00 & 1.95 & 0.00 & 0.00 & 0.00 \\
\hline $\mathrm{TiO}_{2}$ & 15.76 & 12.59 & 13.96 & 12.90 & 16.51 & 14.24 & 13.92 & 14.34 & 7.74 & 9.57 & 13.03 & 11.17 & 15.66 & 12.92 & 16.45 & 14.94 & 15.17 & 15.62 & 13.09 & 13.46 & 13.46 \\
\hline $\mathrm{V}_{2} \mathrm{O}_{5}$ & 0.82 & 0.52 & 0.64 & 1.11 & 0.53 & 0.39 & 0.80 & 0.69 & 0.11 & 0.21 & 0.14 & 0.67 & 0.07 & 0.41 & 0.70 & 0.40 & 0.15 & 1.12 & 0.78 & 0.64 & 0.00 \\
\hline $\mathrm{MnO}$ & 1.31 & 1.16 & 0.98 & 0.81 & 0.93 & 0.96 & 1.12 & 1.13 & 0.00 & 1.20 & 0.77 & 1.34 & 1.54 & 0.92 & 1.00 & 1.15 & 1.15 & 1.61 & 0.95 & 1.22 & 1.12 \\
\hline $\mathrm{FeO}$ & 5.60 & 59.19 & 73.09 & 64.86 & 74.48 & 69.78 & 70.99 & 76.83 & 61.17 & 68.55 & 71.51 & 65.74 & 73.30 & 66.17 & 76.96 & 78.49 & 80.77 & 75.30 & 81.47 & 80.51 & 81.44 \\
\hline
\end{tabular}


рядок более высокую намагниченность 21.88 А/м (см. табл. 3), имеют псевдооднодоменную структуру и в них отсутствует магнитная анизотропия. Величина магнитной восприимчивости была относительно невысока, что отражает концентрацию зерен-носителей остаточной намагниченности.

Образец В1-58/1 имеет средний состав. Основными слагающими минералами являются плагиоклаз, пироксен, окисленный титаномагнетит. Слабая ориентировка микролитов показывает, что окончательная кристаллизация породы происходила в процессе течения лавы при медленном ее подъеме к поверхности. Присутствие окисленного титаномагнетита в виде разноразмерных как вкрапленников, так и микролитов показывает, что формирование минерала происходило на всем протяжении кристаллизации породы, от свободного роста относительно крупных выделений в условиях обилия расплава (возможно, в промежуточном очаге), до выделения микролитов в процессе подъема лавы к поверхности

В образце В1-52/2 вкрапленник окисленного титаномагнетита - поздний, он отмечен внутри газового пузыря. Многочисленные газовые пустоты свидетельствуют о спонтанном выделении газовой фазы и, возможно, взрывном характере извержения. Кристаллизация лавы происходила при относительно низких температурах и слабом течении лавы. Об этом свидетельствуют слабо ориентированные микролиты роговой обманки - минерала, содержащего воду. Соответственно, микролиты окисленного титаномагнетита, синхронного по времени образования с роговой обманкой, являются самыми низкотемпературными в исследуемой серии образцов.

Ферримагнитные зерна образцов афирового андезибазальта В1-52/2 и редкопорфирового андезибазальта В1-58/1 имеют близкие к магнетитовым точки Кюри. Образцы обладали более высокой по сравнению с другими образцами магнитной жесткостью (остаточная коэрцитивной силы 27 мТл), более высокими значениями медианного магнитного поля (70 мТл) и наличием магнитной анизотропией от 4 до $7 \%$ (см. табл. 3). В этих образцах наблюдалась тенденция уменьшения остаточной намагниченности и фактора Кенигсбергера (Qn) с ростом магнитной восприимчивости (см. табл. 3), которую объясняют зависимостью магнитных характеристик от размера зерен [Трухин и др., 2006]. Зерна титаномагнетита содержали некоторое количество изоморфных примесей $\mathrm{Al}$ и $\mathrm{Mg}$, что свидетельствовало об уменьшении шпинельной фазы. Титаномагнетит в этих двух типах пород (в отличие от В1-57/2) выделялся на протяжении всего времени существования лавы, от стояния в очаге до медленного продвижения по каналу и излиянию, которое сопровождалось значительным выделением газовой фазы (как в образце В1-52/2). В результате, как химические, так и магнитные свойства могли отличаться в зависимости от места и условий формирования минерала.

Помимо окисленного титаномагнетита в образце В1-58/1 присутствовал моноклинный пирротин. Пирротин часто встречается в изверженных породах, его спонтанная намагниченность много ниже, чем у титаномагнетита, поэтому высокие величины NRM отобранных образцов лав обусловлены содержанием титаномагнетита.

\section{ЗАКЛЮЧЕНИЕ}

В результате выполненных исследований изучены петромагнитные свойства и структурные и минералого-петрографические особенности образцов горных пород, слагающих постройки подводной вулканической группы Софу в Идзу-Бонинской островной дуге. Дополнена имеющаяся информация о петромагнитных характеристиках горных пород, слагающих подводные вулканы островных дуг Тихого океана, что сделает более достоверной интерпретацию материалов изучения магнитного поля подводных вулканов как в Идзу-Бонинской, так и в остальных островных дугах Тихого океана.

Сравнительный анализ магнитных свойств горных пород показал, что, как и в Соломоновой, Марианской и Курильской островных дугах [Пилипенко, Рашидов, 2013; Пилипенко и др., 2012а, 2012б; Рашидов и др., 2014; Rashidov et al., 2012], они сильно дифференцированы по величине NRM и К. Такая дифференциация связана с присутствием нескольких ферримагнетиков, образовавшихся как в процессе кристаллизации породы, так и после ее изменений в результате вторичных процессов. Установлено, что основными носителями намагниченности в изученных образцах горных пород, слагающих постройки подводной вулканической группы Софу, были псевдооднодоменные зерна неизмененного и окисленного титаномагнетита. Помимо титаномагнетита в породах, слагающих вулканическую группу, имеет место еще один ферримагнетик - моноклинный пирротин.

Работа выполнена при поддержке РФФИ (проект 12-05-00156-а).

\section{СПИСОК ЛИТЕРАТУРЫ}

Аникеева Л.И., Казакова В.Е., Гавриленко Г.М., Рашидов B.A. Железомарганцевые корковые образования западно-тихоокеанской переходной зоны // Вестник. КРАУНЦ. Науки о Земле. 2008. № 1. Вып. 11. C. $10-31$.

Бевзенко П.И. Магматическая эволюция островных дуг Востока Азии // Изверженные породы Востока Азии. Владивосток: ДВГИ ДВНЦ АН СССР, 1976. C. 3-18.

Бенедюк Ю.П. Геохимия и эволюция составов хромшпинелидов ультрабазитов центральной части Восточного Саяна / Автореф. дис. ... канд. геол.-мин. наук. Иркутск, 2013. 22 с. 
Гущенко И.И. Извержения вулканов мира. Каталог. М.: Наука, 1979. $475 \mathrm{c}$.

Дир У.А., Хауи Р.А., Зусман Джс. Породообразующие минералы. В 2-х томах. М.: Мир, 1965. Т. 1. 370 с., Т. 5. $407 \mathrm{c}$.

Дубинин А.В., Успенская Т.Ю., Гавриленко Г.М., Рашидов B.A. Геохимия и проблемы генезиса железомарганцевых образований островных дуг западной части Тихого океана // Геохимия. 2008. № 10. С. 1280-1303.

Нагата T. Магнетизм горных пород. М.: Мир, 1965. 348 с. Паркинсон У. Введение в геомагнетизм. М.: Мир, 1986. $528 \mathrm{c.}$

Печерский Д.М., Багин В.И., Бродская С.Ю., Шаронова 3.В. Магнетизм и условия образования изверженных горных пород. М.: Наука, 1975. 288 с.

Печерский Д.М., Диденко А.Н. Палеоазиатский океан; петромагнитная и палеомагнитная информация о его литосфере. М.: ОИФЗ РАН, 1995. 298 с.

Пилипенко О.В., Рашидов В.А. Петромагнитные исследования горных пород подводных вулканов Идзу-Бонинской и Курильской островных дуг // Геология морей и океанов. Матер. XX Междунар. научн. конф. (Школы) по морской геологии. Москва, 18-22 ноября 2013 г. Москва: ГЕОС, 2013. Т. 5. С. 209-2013.

Пилипенко О.В., Рашидов В.А., Ладыгин В.М. Петромагнитные и петрофизические исследования пород позднекайнозойских подводных вулканов западной части Тихого океана // Палеомагнетизм и магнетизм горных пород. Матер. междунар. школы-семинара по проблемам палеомагнетизма и магнетизма горных пород. СПб.: СОЛО, 2012а. С. 184-191.

Пилипенко О.В., Рашидов В.А., Ладыгин В.М. Петромагнитные исследования пород позднекайнозойских подводных вулканов островных дуг западной части Тихого океана // Матер. II Школы-семинара "Гординские чтения" Москва, 21-23 ноября 2012 г. М.: ИФЗ РАН, 20126. С. 160-164.

Природа магнитных аномалий и строение океанической коры / Отв. ред. Городницкий А.М. М.: ВНИРО, 1996. $283 \mathrm{c}$.

Рашидов B.A. Геомагнитные исследования при изучении подводных вулканов островных дуг и окраинных морей западной части Тихого океана / Автореф. дис. ... канд. т. наук. Петропавловск-Камчатский, 2010. 27 с.

Рашидов В.А., Горшков А.П., Иваненко А.Н. Магнитные исследования над подводными вулканами Эсмеральда и Софу // Изучение глубинного строения земной коры и верхней мантии на акваториях морей и океанов электромагнитными методами. М.: ИЗМИРАН, 1981. C. 213-218.

Рашидов В.А., Пилипенко О.В., Ладыгин В.М. Сравнительный анализ магнитных свойств пород пяти действующих подводных вулканов западной части Тихого океана // Вулканология и сейсмология. 2014. № 3. C. $1-16$.

Рашидов B.A., Сапожников E.A. Геолого-геофизические исследования подводной вулканической группы Софу (Идзу-Бонинская островная дуга) // Вулканология и сейсмология. 2001. № 4. С. 39-47.

Трухин В.И., Максимочкин В.И., Жиляева В.А. и др. Магнитные свойства базальтов и геодинамические особенности рифтовой зоны юга Красного моря // Физика Земли. 2006. № 11. С. 70-83.
Butler R. Paleomagnetism: magnetic domains to geologic terranes. Electronic edition, May 1998. Department of Geosciences University of Arizona, Tucson, Arizona. http:// www.pmc.ucsc.edu/ njarboe/pmagresource/Butler-PaleomagnetismBook.pdf

Day R., Fuller M., Schmidt V.A. Hysteresis properties of titanomagnetites: grain-size and compositional dependence // Physics of the Earth and Planetary Interiors. 1977. V. 13. P. 260-267.

Fujiwara T., Yuasa M., Watanabe T. Submersible study around the Sofugan Tectonic Line, Izu-Bonin Arc // JAMSTEC J. Deep Sea Res. 2001. V. 18. P. 72-82.

Honsa E., Tamaki K. The Bonin Arc // The ocean basins and margins.V. 7A.The Pacific Ocean. Plenum Press. New York and London. 1985. P. 459-502.

Ishihara T. Gravimetric determination of densities of seamounts along the Bonin Arc // Seamounts Islands and Atolls. Geophys. Monogr. Ser. V. 43. Eds. B. Keating et al. 1987. AGU. Washington. P. 97-113.

Ishihara T., Yamazaki T. Gravity anomalies over the IzuOga-Sawara (Bonin) and Mariana Arcs // Bull. Geol. Serv. Japan. 1991. V. 42. № 12. P. 687-701.

Miura S., Sato T. , No T. et al. Wide-angle seismic experiment crossing the Sofu-gan tectonic line in the IzuOgasawara arc - KY0507 cruise // JAMSTEC Report of Research and Development. 2006. V. 3. P. 19-29.

Rashidov V.A., Pilipenko O.V., Ladygin V.M. Petromagnetic investigations of active submarine volcanoes from western Pacific Ocean $/ / 9^{\text {th }}$ International Conference "Problems of Geococmos". Book of Abstracts. St. Petersburg, Petrodvorets, Oktober 8-12, 2012. St. Petersburg, 2012. P. 68-69.

Siebert L., Simkin T., Kimberly P. Volcanoes of the World. Third edition. Smithsonian institution, University of California Press, 2010. 551 p.

Ueda Y. Magnetic and Gravity Field Analyses of IzuOgasawara (Bonin) Arc and Their Tectonic Implications // J. Geomagnetic. Geoelectric. 1996. V. 48. P. 421-445.

Ueda $Y$. Magnetizations of the seamounts in the IzuOgasawara arc with special reference to the origin of their normal polarity biases // Earth Planets Space. 2007. V. 59. P. 897-909.

Yamazaki T., Ishihara T., Murakami F. Magnetic anomalies over the Izu-Ogasawara (Bonin) Arc, Mariana Arc and Mariana Trough // Bull. Geol. Serv. Japan. 1991. V. 42. № 12. P. 655-689.

Yuasa M. Sofugan tectonic line. A new tectonic boundary separating northern and southern parts of the Ogasawara (Bonin) arc, northwest Pacific // Formation of Active Ocean Margins / Eds Nasu N. et al. Tokio: TERRAPUB, 1985. P. 483-496.

Yuasa M. Origin of along-arc geologic variations of the volcanic front of the Izu-Ogasawara (Bonin) Arc // Bull. Geol. Surv. Japan. 1992. V. 43. № 7. P. 457-466.

Yuasa M., Murakami F., Saito E., Watanabe K. Submarine Topography of seamonts on the volcanic front of the IzuOgasavara (Bonin) Arc // Bull. Geol. Serv. Japan. 1991 V. 12. № 12. P. 703-743.

Yuasa M., Nochara M. Petrografhic and geochemical along-arc variations of volcanic rocks on the volcanic front of the Izu-Ogasawara (Bonin) Arc // Bull. Geol. Surv. Japan. 1992 . V. 43. № 7. P. 421-456. 


\title{
Petromagnetic and Microprobe Studies of Rocks \\ in the Sofu Underwater Volcanic Cluster, Izu-Bonin Island Arc, Pacific Ocean
}

\author{
V. A. Rashidov ${ }^{a}$, O. V. Pilipenko ${ }^{b}$, and V. V. Petrova ${ }^{c}$ \\ ${ }^{a}$ Institute of Volcanology and Seismology, Far East Branch, Russian Academy of Sciences, \\ bul'var Piipa 9, Petropavlovsk-Kamchatskii, 683006 Russia \\ e-mail: rashidva@kscnet.ru \\ ${ }^{b}$ Institute of Physics of the Earth, Russian Academy of Sciences, ul. B. Gruzinskaya 10, Moscow, 125395 Russia \\ ${ }^{c}$ Geological Institute, Russian Academy of Sciences, Pyzhevskii per. 7, Moscow, 119017 Russia \\ Received October 5, 2014
}

\begin{abstract}
A multidisciplinary study of samples that were dredged during cruises of the R/V Vulkanolog was continued in order to interpret results from a survey of the anomalous magnetic field on the Pacific seafloor. We acquired data on the main ferromagnetic carrier and the nature of magnetization. The naturally occurring magnetic parameters and petromagnetic properties of the rocks that make up the edifices of the Sofu underwater volcanic cluster at the Izu-Bonin island arc have been studied. We provide the results of thermomagnetic, petrologic, and microprobe studies of the dredged samples. It is shown that the main magnetic mineral carriers of natural remanent magnetization are unaltered titanomagnetite and oxidized titanomagnetite. The differentiation of rocks over values of natural remanent magnetization was due to different crystallization conditions for titanomagnetite, while that over magnetic susceptibility was controlled by the magnetic grain size. The structural, mineralogic, and petrographic features of the samples show that they were taken from rocks that were discharged during different phases of eruptions.
\end{abstract}

